\title{
FLEXIBLE HOUSING SCHEMES ON HOUSING TYPE 36 IN YOGYAKARTA
}

\author{
Hendra Frisky ${ }^{1 *}$, Diananta Pramitasari ${ }^{2}$ \\ ${ }^{1}$ Department of Architectural, Institut Teknologi Sumatera, Lampung, INDONESIA \\ ${ }^{2}$ Department of Architectural and Planning, Universitas Gadjah Mada, Yogyakarta, INDONESIA \\ *Corresponding author; Email: hendra.frisky@ar.itera.ac.id
}

\begin{abstract}
Flexible housing has the potential to be applied in housing type 36 in Indonesia, especially with a focus on the modeling of the flexible housing scheme. But beforehand, potential redundancies and trend patterns of occupant needs must be identified. The research stages are spaciousness, spatial complexity using statistics, and perceptual clarity using repeated modeling and evaluation. There are 28 research data samples taken from type 36 housing developed by Perum perumnas Regional V of Yogyakarta branches i.e. Perumnas Minomartani, Perumnas Condong Catur, Perumnas Guwosari, and Perumnas Trimulyo. The results of the research are change of rooms needs for the Inhabitant, transformation of typology from the house layout, the priority setting of rooms for the inhabitants, linkage among rooms that is efficient for the Inhabitant, limitations of flexible housing, and flexible housing schemes.
\end{abstract}

Keywords: Flexible housing; housing Type 36; Yogyakarta.

\section{INTRODUCTION}

Schneider and Till (2007) described that flexible housing is the concept of housing that can adapt with the development of the inhabitants' needs in a certain period (life cycles), in the climax (increase) or anticlimax (decrease). This concept is believed to be able to support "Program Satu Juta Rumah" launched by the government to make it more optimal because it does not only focus on quantity but also the quality of housing. According to Frisky and Pramitasari (2018), in a review paper entitled "Flexible Housing: Architectural Investment for Future House," this concept has the potential to be applied to type 36 housing in Indonesia, especially with a focus on modeling the flexible housing scheme Housing type 36 is a house with a building area of $36 \mathrm{~m} 2$. Based on UndangUndang Republik Indonesia No. 1 tahun 2011, the floor area of a single healthy house and row house has a minimum size of $36 \mathrm{~m} 2$.

Simply put, the flexible housing concept is an open building concept with movable panel walls. The current innovation is dominated by hard analogy in the form of panel wall technology that is easy to move. But sometimes, we forget to plan soft analogies in the form of schematic modeling or strategies to move hard analogies effectively. Before getting to schematic modeling, one of the most important things in this concept is the extent to which an architect is able to identify the potential redundancies from occupant needs. The redundancy potential can be measured by reading their trend patterns. This trend pattern is used as the basis for scenarios and stimuli in the modeling process later. The trend pattern is influenced by several variables so that each sample area has certain characteristics. This makes it impossible to generalize the trend patterns in Indonesia.

Based on the background and situation above, the researchers compiled a paper entitled "Flexible Housing Schemes on Housing Type 36 in Yogyakarta". This paper aims to identify (1) the morphological processes found in housing type 36 in Yogyakarta and (2) a better flexible housing scheme for the initial planning of housing type 36 .

\section{THEORETICAL REVIEWS}

The basis of the flexible housing concept is a space that undergoes a transformation process. Meanwhile, the transformation itself is an adaptation response from space. In order to proceed to the modeling of the flexible housing scheme, it is necessary to have modular as the basis of the physical configuration (Diagram 1). Based on the theoretical framework, there are five variables used in this study, namely space as the independent variable, flexible housing as the dependent variable, transformation as an intervening variable, adaptation and modular as moderating variable.

Space theory requires a hierarchy in determining the most prioritized space requirements. According to Ching (2008) and Franklin (2006), the hierarchy of space is derived from the interrelationship between necessity, organizational pattern, relationships, and 
clarity. The transformation indicators according to Ching (2007), Habraken (1982), and Franklin (2006), are additive transformation (addition); subtractive transformation (elimination); dimensional transformation; position transformation (movement); and orientation transformation. According to Franklin (2006), adaptation responses are influenced by social, economic, political, and cultural factors. The theory of adaptation affects the saturation level of potential redundancy but will make this research very broad. Therefore, it only focuses on internal problems, or better known by Schnädelbach (2010), with the terms human intervention and inhabitant focused.

\section{Morphology}

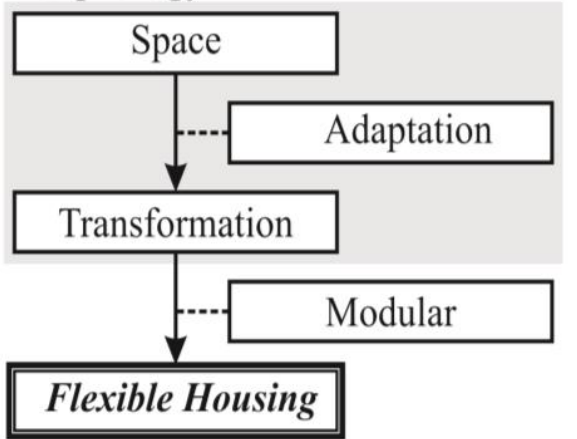

Diagram 1. Theoretical Framework
According to Schneider and Till (2007), flexible housing starts from hard to soft. Before drawing up the scheme, it is necessary to identify the flexibility of the elements of the housing. Basically, all the elements that are part of the house can be moved, but it costs extra. Permanent elements can be made temporary to reduce these costs. However, there are some elements that cannot be changed to temporary because apart from requiring high costs, they also have special installations. The inflexible element, which will be the limiter in the flexible housing scheme, are modular coordination, space dimension, service space, frame, structure, and entrance element.

\section{METHOD OF RESEARCH}

The approach method uses modeling stimulation of Earlier Stages of the Architectural Design Process that is adapted from Wang (2013). In addition, it is correlated with the modeling method of Fawcett, et al. (2012) and Schnädelbach (2010). The first stage is spaciousness; the second stage, spatial complexity using statistics. The third stage is perceptual clarity, using repeated modeling and evaluation (Diagram 2). Each stage of the analysis will always make a correlation between physical (shelter) and nonphysical (occupants' wishes) so that the actual needs of the inhabitants are completely saturated.

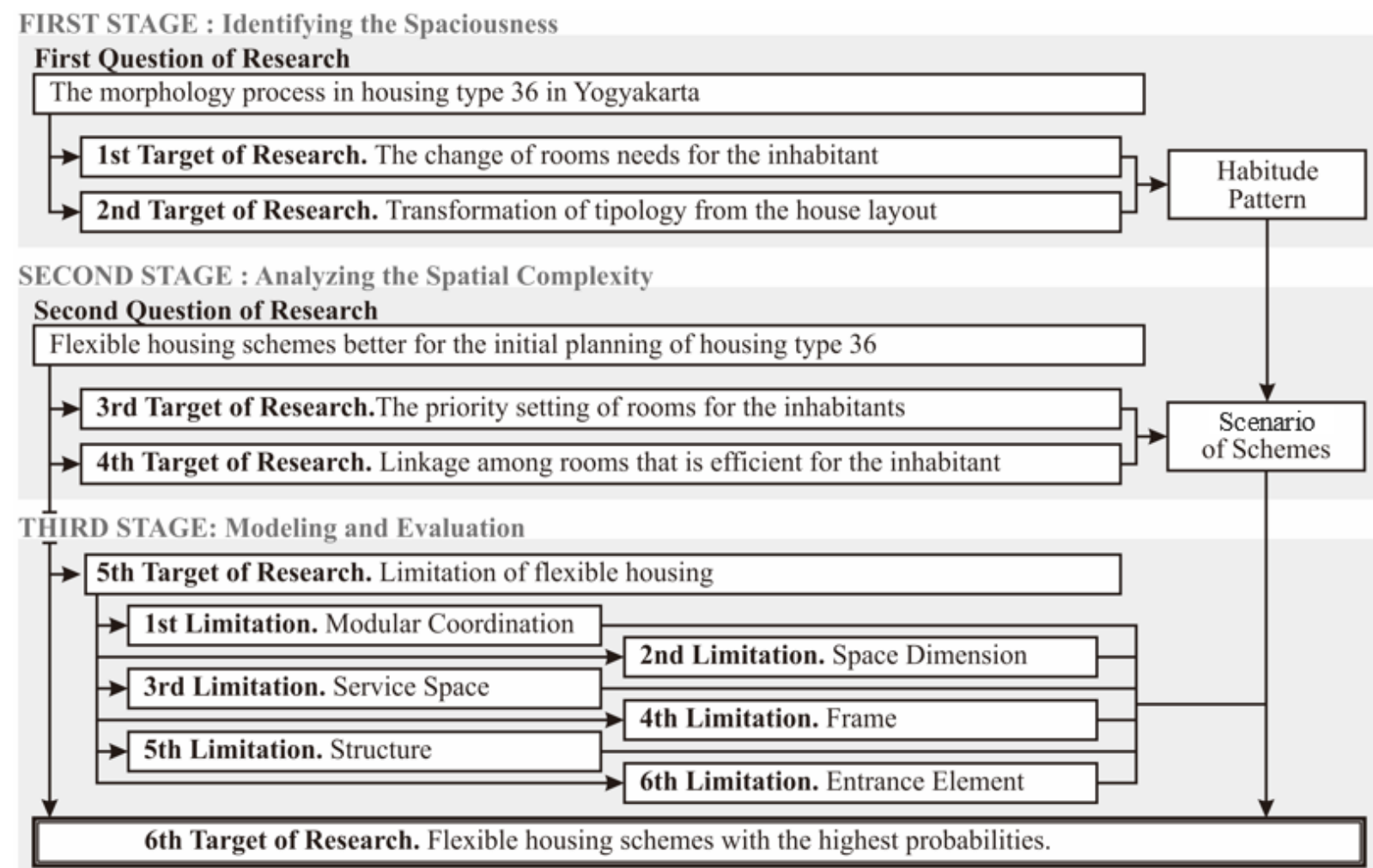

Diagram 2. Research Framework 


\section{DATA AND ANALYSIS}

The research data sample was taken from type 36 housing developed by Perum perumnas Regional $\mathrm{V}$ of Yogyakarta branches i.e. Perumnas Minomartani, Perumnas Condong Catur, Perumnas Guwosari, and Perumnas Trimulyo. There are 28 samples which are purposive sampling with the characteristics as follow: (1) the housing type is 36 , which is single or clusters; (2) it has undergone the architecture transformation (renovation); (3) it is bought and inhabited for more than five years; and (4) if possible, it has been renovated by the last owner, as the respondent. There are two types of data taken from this sample, namely physical data based on observations and nonphysical data based on interviews. Physical data are in the form of house plans from the early stages to the present. Meanwhile, non-physical data is inhabitants' wish. All data relating to spatial proximity, spatial priority order, and multiple adaptation responses.

From all samples, six types of the initial layout were identified. Interestingly, there are three types of initial layouts that have a bathroom entrance from the outside of the frame. Hierarchically, the position of the entrance makes the bathroom separate from the main building, even though it is physically attached. This type of layout is very rarely found in housing developed by Perum Perumnas in other areas.

The analysis process in the first stage is carried out only by reading the data obtained in the field and comparing them in several phases. This analysis is not as complex as the analysis in the second stage, so the process is immediately described in Results and Discussion. In the second stage of analysis, the level of priority space requirements is analyzed using the Spearman's Rank Correlation method, while the linkage between rooms is analyzed using the ChiSquare Test method. The degree of correlation from the above analysis will determine the means that are going to be used as the conclusion. There are three types of means, namely based on the inhabitants' wishes, house layout, and both.
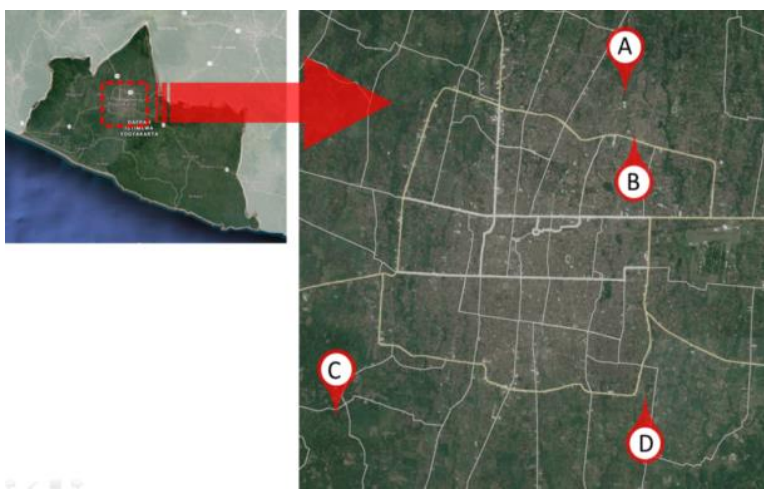

Fig. 1. Sampling Location (a) Perumnas Minomartani; (b) Perumnas Condong catur; (c) Perumnas Guwosari; dan (d) Perumahan Trimulyo.

In the third stage of analysis, researchers identify the flexible boundary housing that will be used as the basis for modeling the flexible housing scheme. There are 2 out of 6 types of constraints that must be analyzed using statistics. First, modular coordination is analyzed using Hypothesis Test, which is categorized as one mean, $\mathrm{n}<30$, and the population is not declared NORMAL distributed. Second, the spatial dimension is analyzed using the Hypothesis Test, which is categorized as two means, a small sample and the same population variance.

\section{RESULTS AND DISCUSSION}

\section{The Change of Rooms Needs for the Inhabitant}

The change of the inhabitant's needs of the room is influenced by some factors such as the inhabitant's finances (economy), age, habits (culture), and knowledge about architecture (education). The change of the inhabitant's needs does not have a certain planning pattern and still depends on the economic factor. The high level of the economy makes inhabitants more likely to follow their wishes, more than what they need. Meanwhile, the low economic level makes them suppress the need to follow the existing physical housing. This can be seen from the correlation between the inhabitants' wishes with a high economic level which is very different (higher) with their current occupancy conditions.

The age of the occupants also has unique characteristics when compared to economic factors, which can be directly or inversely proportional. As we get older, a person's financial condition tends to improve, and desire increases. But at some point from the age of the occupants, which causes a decrease in desire, even though the economic level increases.

The pattern of changing the needs of the inhabitants is also shaped by the habits (culture) in treating certain spaces. Although it depends on the economic level, but the needs changing that requires a high cost to fulfill the cultural factor is still implemented. One example is the placement of a bathroom outside the frame, or there are even occupants who require a certain orientation. Some anomaly samples usually come from inhabitants who come from outside Java. In addition, with the educational factor, inhabitants are able to distinguish between wishes and needs, and the change process is more planned and tends to be balanced with the economic level.

Based on the typology transformation process of the house layout, each room has a certain trend pat- 


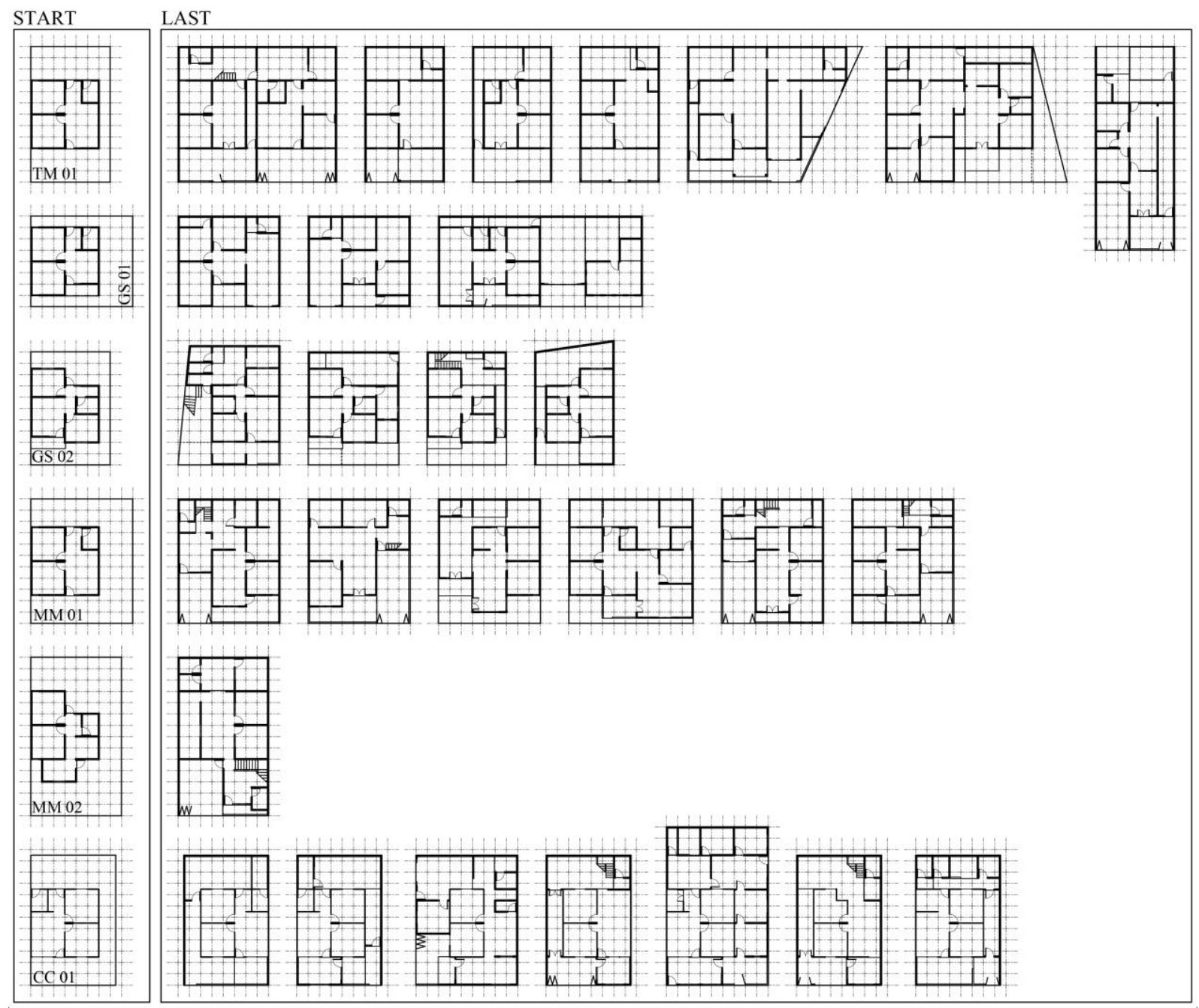

Fig. 2. The transformation process from six initial layout

tern. However, there are three rooms that have a very dominant trend compared to other rooms, namely the position transformation of the bathroom, dry kitchen, and wet kitchen. These three spaces are part of the service space, which becomes the divider for the flexible housing scheme. In the placement of the bathroom, there were 18 out of 28 samples (64.2\%) who transformed the position outside the frame to the rearmost and most angular point of the house. Of the 18 samples, 16 samples (57.1\%) immediately transformed their position in the first renovation process, and the rest $(7.1 \%)$ were done in the second renovation process. Thus, it can be concluded that the value of the urgency of the position transformation of the bathroom is in the very high category.

The assumption regarding a dirty bathroom does not occur because the bathroom entrance is outside the frame. This type of layout is planned to respond to the culture of the people of Yogyakarta, which separates 'dirty' areas. Of the 28 samples, 17 samples $(60.7 \%)$ were house layouts with bathroom entrances outside the frame, whereas 11 samples (39.2\%) continued to transform positions. So the reason for the area to be "dirty" is not entirely correct, but there is also one in the form of high humidity in the house, which is essentially unhealthy for the occupants. Based on Keputusan Menteri Permukiman dan Prasarana Wilayah No. 403/KPTS/M/2002, the bathroom is planned to be completely separated from the main building to maximize the health of the home. Unfortunately, until now, the initial housing layout design has not been planned to comply with these regulations. Yet the behavior of inhabitants in Yogyakarta forms its own pattern, initial layouts of their homes tend to be transformed into layouts that comply with these regulations.

Meanwhile, dry kitchens also have a tendency to carry out a positive transformation, following the position of the bathroom. There were 27 out of 28 samples $(96.4 \%)$ who performed a position transformation, of which 17 samples $(60.7 \%)$ were located very close to the bathroom. From this closeness, there are 11 samples (39.2\%) who transformed the position of the bathroom and dry kitchen simultaneously in one 
Table 1. The position transformation position of the service room in housing type 36 in Yogyakarta

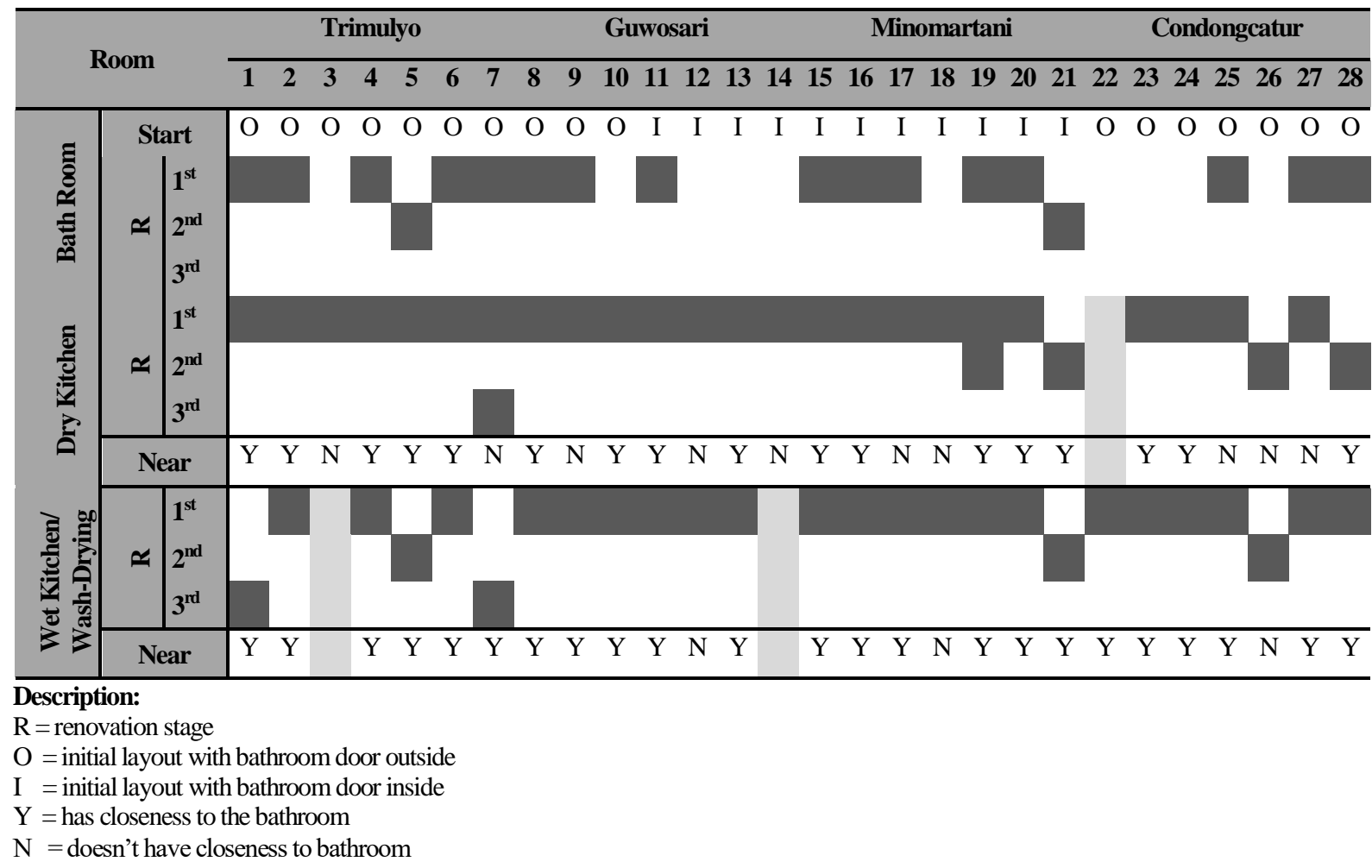

renovation stage and one sample (3.5\%) who transformed the position of the dry kitchen after one stage of renovation after the position transformation of the bathroom. Therefore, it can be concluded that the bathroom and dry kitchen seem to "move" like a whole.

Apart from position transformations, there are other types of transformations that are resulted by the inhabitants. In fulfilling the increasing needs, almost all samples undergo additive transformations to fill the site. There were 26 of the 28 samples (92.8\%) who transformed the additive in the form of a wet kitchen/washing-drying, whereas 23 samples $(82.1 \%)$ were close to the bathroom. There will be an adjustment of the space dimension through dimensional transformation when the site is not possible to do additive transformation. Increasing the area of space is done by reducing the area of other rooms based on priority levels. In addition, several samples carried out orientation transformations to certain rooms in an effort to improve the hierarchy. However, all samples are unable to carry out subtractive transformations in response to decreasing demand. There are inhabitants who have been left behind, either by their spouses who passed away or by their children who have their own families. They feel that their house is too large, so they need a smaller house.

Given this more dynamic morphological process, particularly the orientation transformation, there are indications that the flexible housing concept is starting to emerge naturally. However, it has not yet entered a stage that can handle the subtractive transformation process. In fact, at the end of the 1970s, researchers assessed that Perumnas Condong catur had implemented the flexible housing concept indirectly. This is evidenced by house sample number 22 , which is inhabited by families with low economic levels. They are the only inhabitants who have retained the entire original material of the house until now. The material is asbestos which is arranged like a wall panel that is easy to be moved (Figure 3). In fulfilling their needs, they only moved the panel walls, either changing the size of the room or increasing the amount of space.

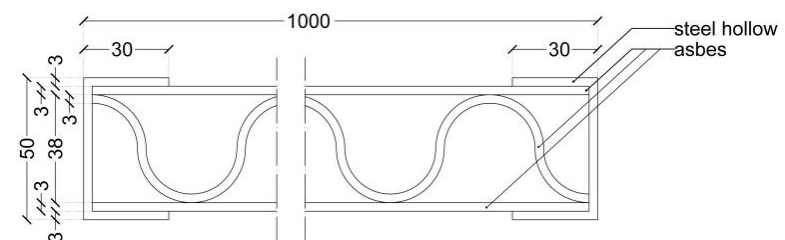

Fig. 3. Asbestos construction as the wall panel of the Condong Catur Housing

\section{The Priority Setting of Rooms for the Inhabitants}

Based on the analysis of the priority order of space requirements for inhabitants of the house, there are 24 out of 28 samples (85.7\%) that have a correla- 
tion between inhabitants' wishes and their house layout. Based on additional observations, two of the four samples that have no correlation are likely to be anomalous or have different orientations regarding needs. The tenth sample, the AAM, has a fairly high financial capacity so that it emphasizes wishes more than actual needs. While the 19th sample, the UBR family has other needs that are beyond the discussion of this research. Based on this dominant correlation, the mean of the overall order of priority needs can be used as a conclusion. The three adjacent mean values make the order of space priority based on the wishes of the occupants, and the house layout can still be used as an optional addition. On closer inspection, the initial six to seven space requirements of the three means have something in common. This indicates two opposites, namely: Perum Perumnas is able to meet the initial space requirements of the occupants, or the occupants' wishes are influenced by the existing physical buildings.

\section{Linkage among Rooms that is Efficient for the Inhabitant}

Of the 15 rooms, a composition of 105 pairs of rooms was analyzed for the proximity between the rooms. Based on the results of the analysis, there are four pairs of spaces categorized into the high proximity category, 25 pairs of spaces that fall into the medium proximity category, and the rest have no closeness. The results of this analysis are arranged in the form of a diagram which can be seen in Diagram 3. Correlated with the results of discussion about service space, the three spaces have a proximity value. A dry kitchen with a wet kitchen/washing-drying is in the high category, while the bathroom with a dry kitchen and a wet kitchen/washing-drying is in the low category. With the similarity results of the two discussed types, the three spaces of the service space can be positioned as a unit.

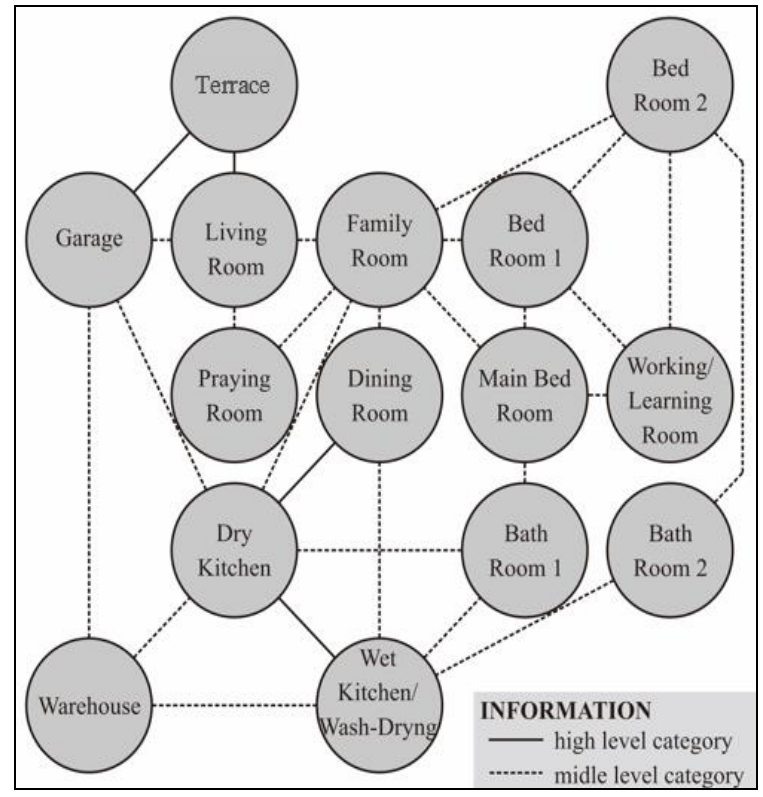

Diagram 3. Linkage among Rooms that is efficient for the Inhabitant

Table 2. The Order of space requirements by priority

\begin{tabular}{clll}
\hline RANK & \multicolumn{1}{c}{ INHABITAT WISH } & LAYOUT OF HOUSE & \multicolumn{1}{c}{ ALL } \\
\hline $\mathbf{1}^{\text {st }}$ & Main Bed Room & Living Room & Main Bed Room \\
$\mathbf{2}^{\text {nd }}$ & Bath Room 1 & Family Room & Bath Room 1 \\
$\mathbf{3}^{\text {rd }}$ & Living Room & Dry Kitchen & Living Room \\
$\mathbf{4}^{\text {th }}$ & Dry Kitchen & Main Bed Room & Dry Kitchen \\
$\mathbf{5}^{\text {th }}$ & Family Room & Bed Room 1 & Family Room \\
$\mathbf{6}^{\text {th }}$ & Bed Room 1 & Bath Room 1 & Bed Room 1 \\
$\mathbf{7}^{\text {th }}$ & Terrace & Terrace & Terrace \\
$\mathbf{8}^{\text {th }}$ & Wet Kitchen/ Wash-Drying & Wet Kitchen/ Wash-Drying & Wet Kitchen/ Wash-Drying \\
$\mathbf{9}^{\text {th }}$ & Dining Room & Garage & Garage \\
$\mathbf{1 0}^{\text {th }}$ & Garage & Dining Room & Bed Room 2 \\
$\mathbf{1 1}^{\text {th }}$ & Bed Room 2 & Bed Room 2 & Dining Room \\
$\mathbf{1 2}^{\text {th }}$ & Praying room & Bath Room 2 & Warehouse \\
$\mathbf{1 3}^{\text {th }}$ & Warehouse & Warehouse & Praying room \\
$\mathbf{1 4}^{\text {th }}$ & Working/ Learning Room & Praying room & Bath Room 2 \\
$\mathbf{1 5}^{\text {th }}$ & Bath Room 2 & Working/ Learning Room & Working/ Learning Room \\
\hline
\end{tabular}

Table 3. Results of linkage analysis between spaces

\begin{tabular}{|c|c|c|c|c|c|c|}
\hline \multirow{2}{*}{ NO } & \multirow{2}{*}{ CHARACTERISTIC } & & \multirow{2}{*}{$\mathbf{n}$} & \multicolumn{3}{|c|}{ LINK } \\
\hline & & & & HIGH & MID & LOW \\
\hline 1. & Have correlation & & 13 & 1 & 5 & 12 \\
\hline 2. & No correlation, but the mean value of the three links is the same & & 80 & 1 & 10 & 69 \\
\hline 3. & No correlation and value in common & & 12 & 2 & 10 & 0 \\
\hline & & Total & 105 & 4 & 25 & 81 \\
\hline
\end{tabular}




\section{Limitations of Flexible Housing}

1. First Limitation: Modular Coordination

Based on the inhabitants' wishes, there are 19 out of 28 samples $(67.8 \%)$ who tend to be influenced by the initial modular in determining the desired spatial dimensions. Meanwhile, based on the spatial layout, there are 27 out of 28 samples (96.4\%) who tend to be influenced by the initial modular in determining the spatial dimensions for transformation. From this dominant result, it can be concluded that modular coordination is very important in developing flexible housing scenarios.

There are five points of detailed modular coordination, i.e., the characteristic of approach, namely combination planning, the kind such as multimodular grid, the position such as face to the grid, the size of intermediate gridelines in $(60 \times 60) \mathrm{cm} 2$, and the application of start point system in the whole building. The determination of the intermediate gridelines size is obtained from finding the common multiple of the material sizes commonly found in Indonesia.

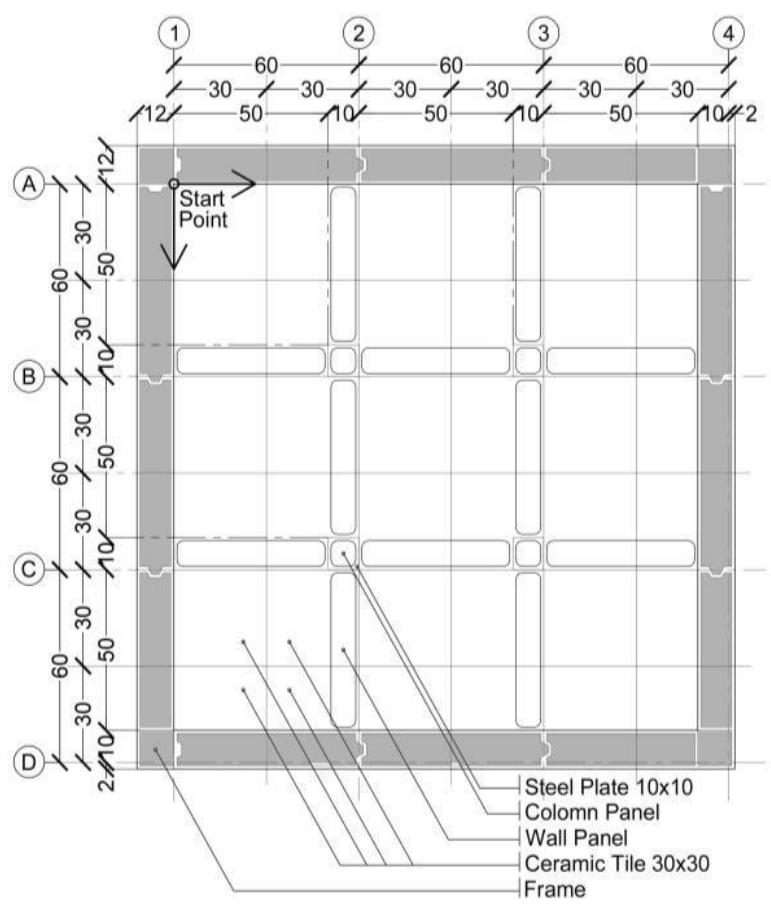

Fig. 4. Modular coordination

2. The Second Limitation: Space Dimension.

Based on the correlation between space dimensions based on occupants' wishes and dimensions based on house layouts, only four out of 15 rooms (26.7\%) have a correlation, namely: dining room, work/study room, warehouse, and prayer room. Space dimension is based on the needs of the inhabitant, but at least it can fulfill the basic needs of each space and can be developed for the distribution of spaces needed by the society of Yogyakarta generally. The distribution value of each space is gained by the intersection $(\cap)$ of the three space dimension intervals based on the wish of the inhabitant, the layout of the house, or holistically. Starting from this discussion and later on, the unit of space dimension is converted into intermediate gridelines.

3. The Third Limitation: Service Space.

Service space is a space that is hard to be moved (inflexible) because it has a specific installation such as the bathroom, wet kitchen, and dry kitchen. These three rooms are grouped based on the pattern of the tendency of the society of Yogyakarta as well as the analysis of linkage among rooms. Besides that, there are three rooms that are categorized into semi-flexible rooms such as terrace, warehouse, and garage. These rooms do not have specific installations, but their positions are decided based on some considerations. Meanwhile, the other rooms may be treated in a flexible manner.

4. The Fourth Limitation: Frame.

The frame is the outermost wall of a building (shell), where each shape and size produces a probability of displacement, which is inversely proportional. The simpler the shape, the higher the probability.

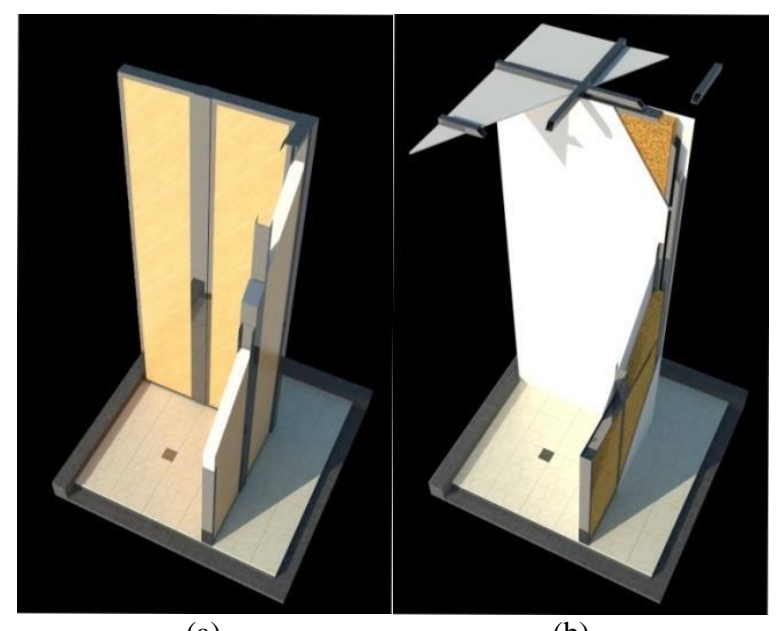

(a)

(b)

Fig. 5. Wall Panel (a) prefabrication, (b) conventional

5. The Fifth Limitation: Structure.

The structure depends on the inhabitant, the column size and wood are adjusted with the load of construction. The placement of column that is dealing with a certain element is done by cutting and not sliding the element and the placement of beam may not touch the ceiling height. 


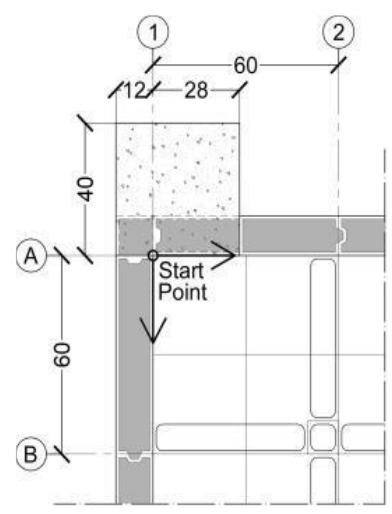

(a)

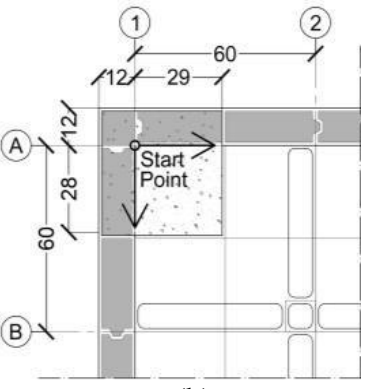

(b)

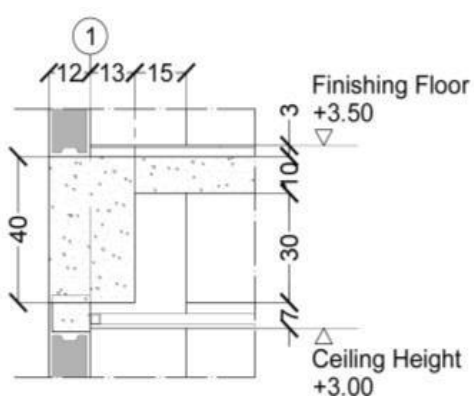

(c)

Fig. 6. Structure placement model: (a) column 30/30 type A; (b) column 30/30 type B; and (c) beam 20/30

6. The Sixth Limitation: Entrance Element.

The entrance element is an entrance between rooms, i.e., door, window, and stairs, where its position and size may influence the movement probability. The size of the door recommended is $90 \mathrm{~cm}$ until 110 in wide and $210 \mathrm{~cm}$ in height plus $30 \mathrm{~cm}$ for ventilation (total $240 \mathrm{~cm}$ ). The window size is $50 \mathrm{~cm}$ in width, and the height depends on the wish of the inhabitant, but it should be parallel with the door. Meanwhile, the position of the stairs is considered as a service space
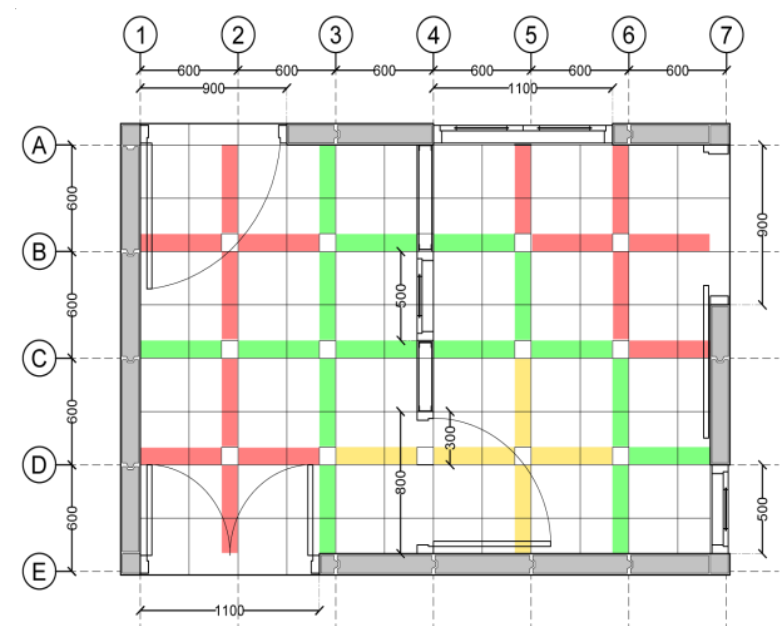

Fig. 7. Entrance element placement model

\section{Flexible Housing Schemes}

He flexible housing schemes are recommended based on the initial layout with the highest probability. This scheme may also respond to the changing needs with the movement as minimum as possible based on the scenario per period. The transformations may be as follow: the change of space composition with the same layout, the addition of layout width with an additional number of floor, the addition of layout width with the additional house unit, and the declined needs of space. Besides that, the recommendation is given based on Keputusan Menteri Permukiman dan Prasarana Wilayah No. 403/KPTS/M/2002 about Pedoman Teknis Pembangunan Rumah Sederhana Sehat where it becomes the limitation of flexible housing.

1. First recommendation

The first recommendation (Figure 8) is the type 36 Housing with open building area of $28.8 \mathrm{~m} 2$ ( 80 intermediates grid lines) that is located in the effective site of a minimum of $72 \mathrm{~m} 2$ (200 intermediates grid lines). The initial layout applies the simplest limitation of flexible housing, and it may be developed into at least 11 schemes (Diagram 4). Building Coverage Ratio of $60 \%$, allowing the base of this house to grow to an area of only 43.2 m2 (120 intermediates grid lines). Therefore, researchers only need to control the transformation of the basic building additives as much as $7.2 \mathrm{~m} 2$ (20 intermediates grid lines).

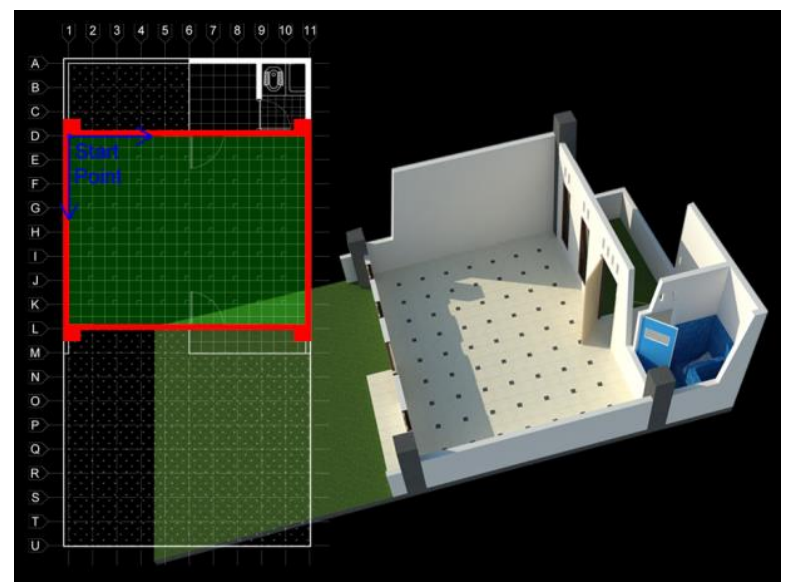

Fig. 8. First layout (first design recommendation)

2. Second recommendation

The second recommendation (Figure 9) has an open building area of $30.6 \mathrm{~m} 2$ ( 85 intermediates grid lines) that is situated in an effective site approaching maximum size, i.e., $86.4 \mathrm{~m} 2$ (240 intermediates grid lines). The initial layout is stimulated by more complex limitations of flexible housing, and it may be developed into at least seven 
schemes (Diagram 5). Based on Building Coverage Ratio, the basic area of this house is able to grow to an area of $51.84 \mathrm{~m} 2$ (144 intermediates grid lines). Researchers have to control the transformation of the additive for the building base of $15.84 \mathrm{~m} 2$ (20 intermediates grid lines).

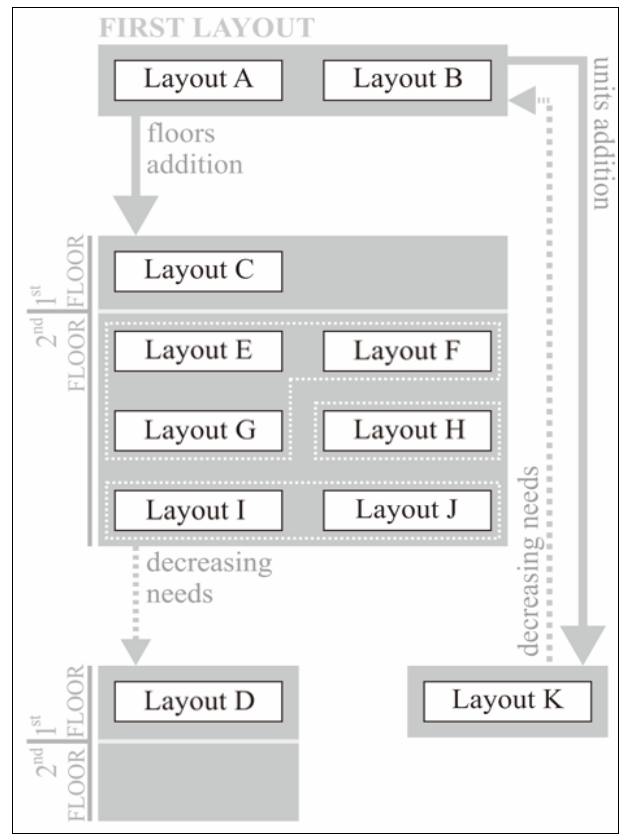

Diagram 4. First scheme recommendation

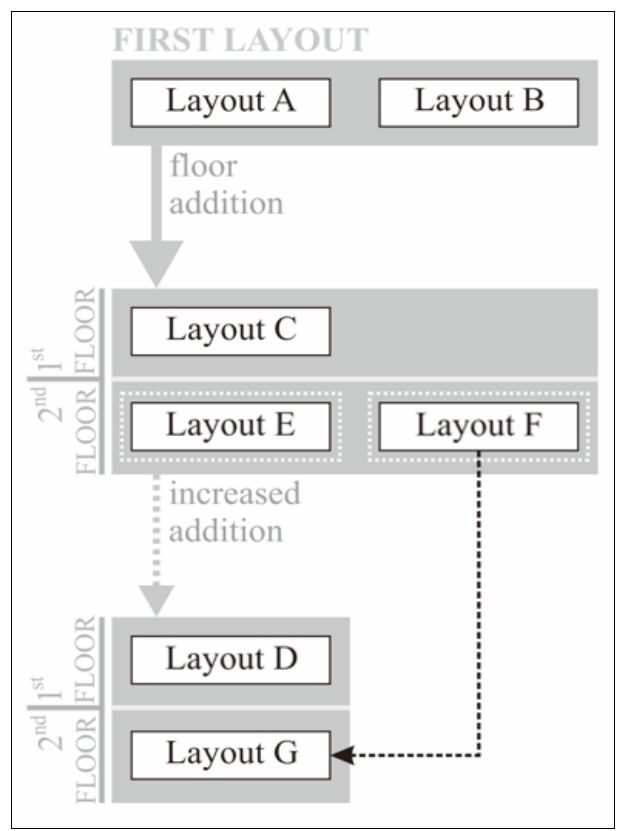

Diagram 5. Second scheme recommendation

\section{CONCLUSIONS}

The type 36 Housing developed by Perum Perumnas in Yogyakarta is experiencing a dynamic morphology process and tends to establish a certain pattern. This is influenced by changes in occupant needs which correlate with the typological transformation of the house layout. The results that can be concluded from this process are:

The change of Rooms Needs for the inhabitant is influenced by some factors such as the inhabitant's finances (economy), age, habit (culture), and knowledge about architecture (education).

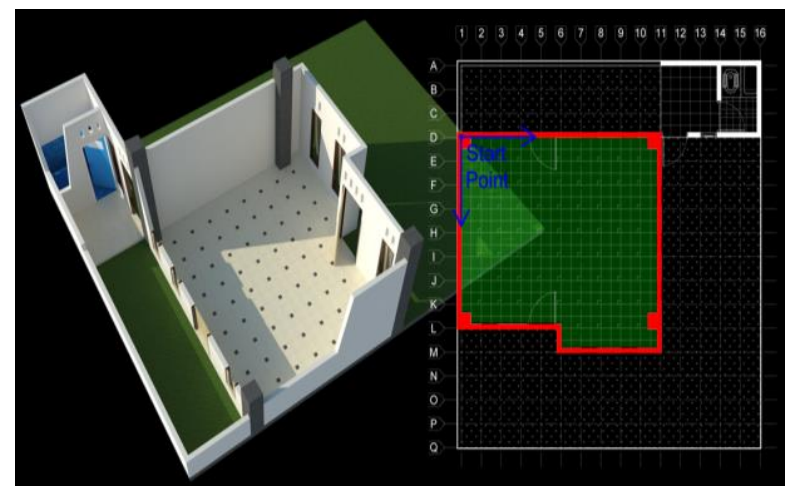

Fig. 9. First layout (second design recommendation)

The transformation of typology from the house layout, all kinds of transformation occur to respond to the inhabitant's needs changing in additive, subtractive, dimensional, orientation, or position transformations.

This dynamic transformation process can be overcome by the flexible housing concept, both in the initial layout planning and in the change scheme. It is necessary to prioritize the needs of saturated inhabitants and the level of proximity between spaces in developing scenarios in a flexible housing scheme, considering the hierarchy of space as an indicator of quality housing. The results that can be concluded from this process are:

1. The change of Rooms Needs for the Inhabitant is influenced by some factors such as the inhabitant's finances (economy), age, habit (culture), and knowledge about architecture (education).

2. The transformation of typology from the house layout, all kinds of transformation occur to respond the inhabitant's needs changing in additive, subtractive, dimensional, orientation or position transformations.

This dynamic transformation process can be overcome by the flexible housing concept, both in the initial layout planning and in the change scheme. It is necessary to prioritize the needs of saturated inhabitants and the level of proximity between spaces in developing scenarios in a flexible housing scheme, considering the hierarchy of space as an indicator of quality housing. The results that can be concluded from this process are: 


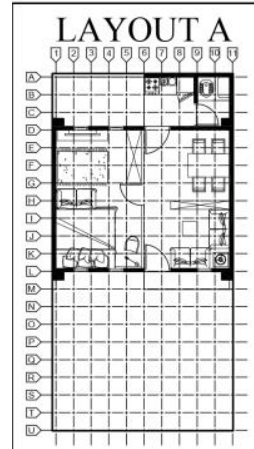

LAYOUT G

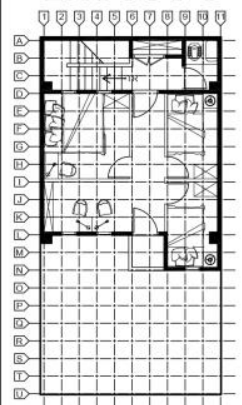

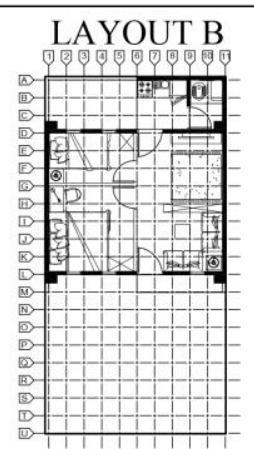
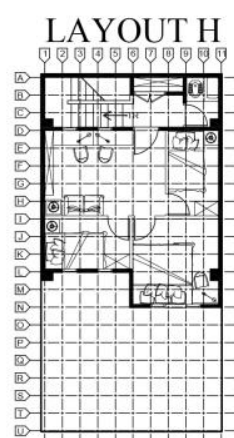
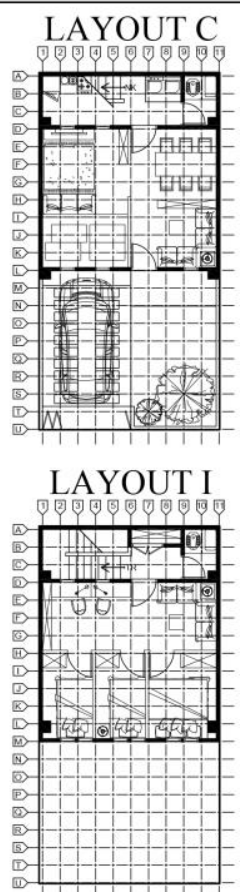
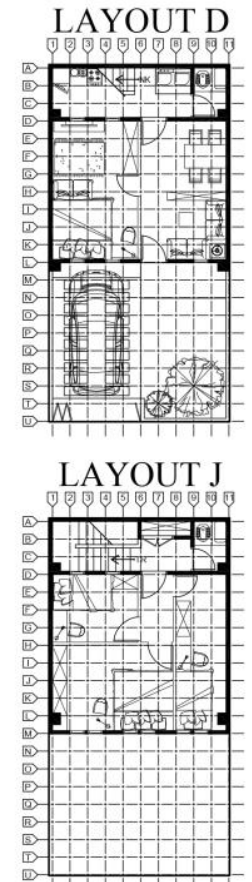
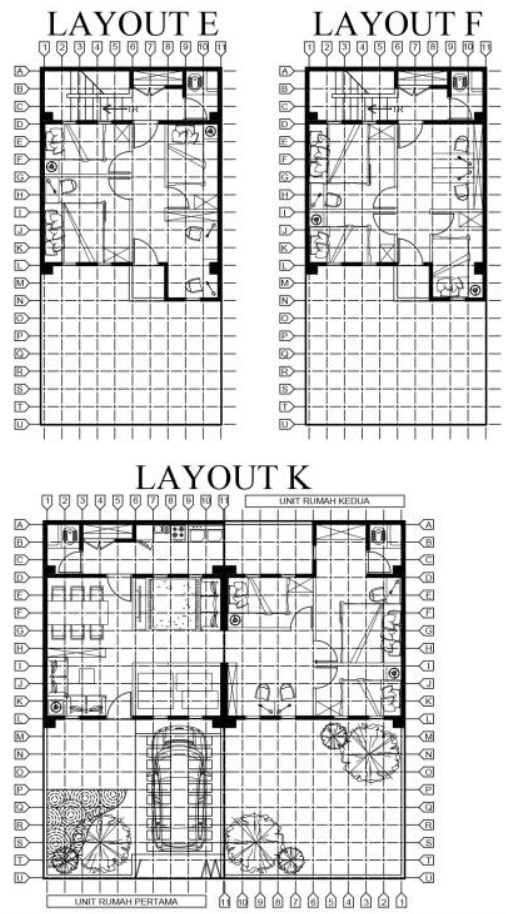

Fig. 10. The type of layout from the first design recommendation

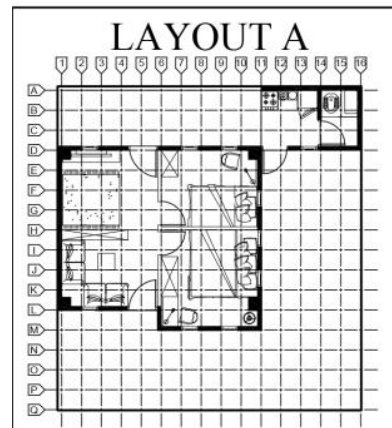

LAYOUT E

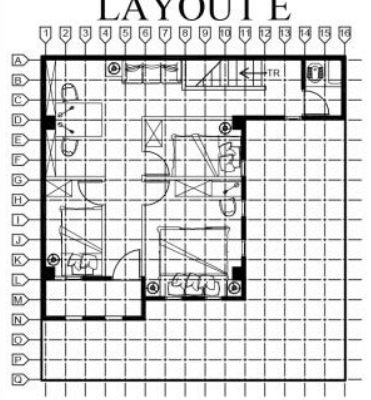

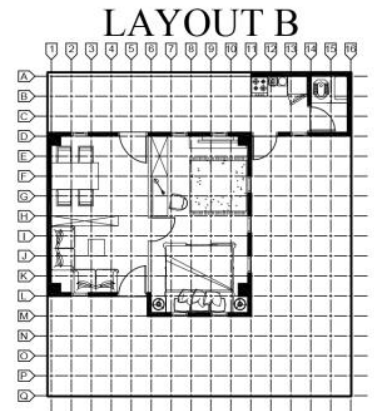

LAYOUT F

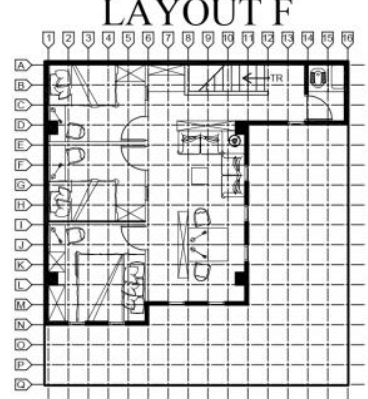

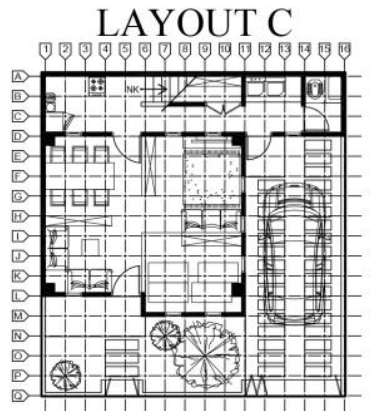
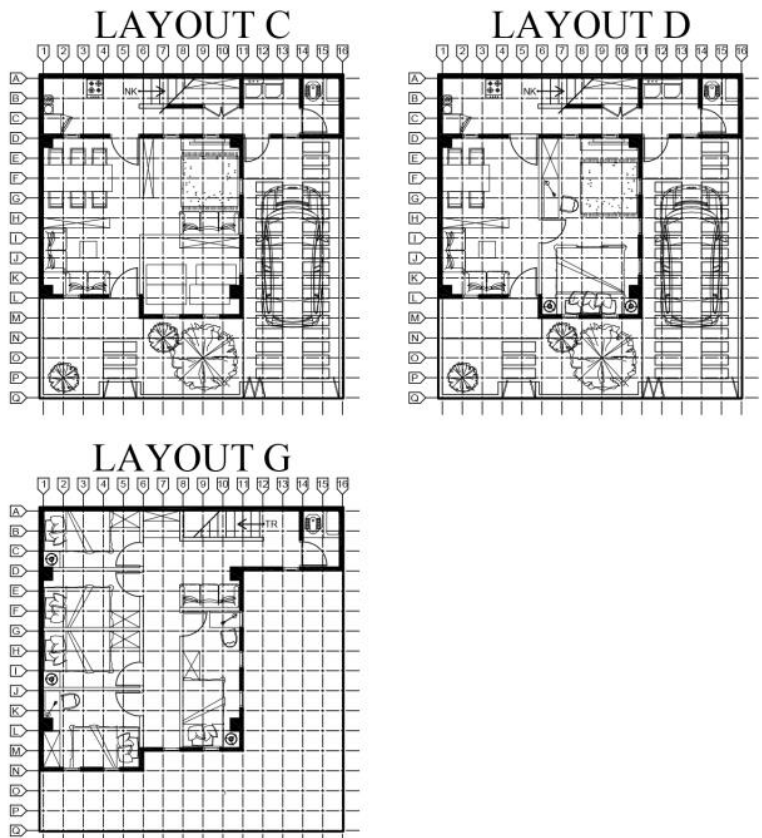

Fig. 11. The type of layout from the second design recommendation

1. Based on the priority setting of rooms for the inhabitants, there is a correlation between the inhabitant's needs and the housing layout. Six or seven rooms from the initial layout provided by Perum Perumnas are able to meet the initial space requirements of the inhabitants of the house. It can also indicate that the occupants' wishes are influenced by the physical building.
2. Based on linkage among rooms, from 15 rooms, there are 105 pairs of space analyzed for linkage, where four rooms are in the high-level category of linkage, 25 rooms are in the middle-level category, and the rest does not have the linkage. The concept of flexible housing itself requires an inflexible element that becomes the boundary for the flexible element, in which there are six boundaries used in 
this paper, namely: modular coordination, spatial dimensions, service space, frame, structure, and entrance element. Of all the components above, a scenario of a flexible housing scheme is compiled into a certain time period. Starting with the initial layout planning that has the highest probability of space transformation and is also able to respond to changing needs with the least possible movement.

From the two recommendations, it can be concludeed that a contradiction that arises when the area of the site is increased helps the process of building a house with the usual core house concept but eliminates the "control" of space from the flexible housing concept. From this contradiction, the researcher realized the level of difficulty Schneider and Till (2005) experienced in applying the concept of flexible housing to each house that was built individually. The very small number of "limits" causes the probability of the scheme to be very high, making it more difficult to control its flexibility, where "control" of the house is the obligation of the subject of the house, especially the architect and its inhabitants. In conclusion, this concept of flexible housing is able to answer the challenges in the research background by maximizing the development of type 36 housing on-site with minimal size, especially in urban areas.

\section{REFERENCES}

Albostan, D. (2009). Flexibility in Multi-Residential Housing Projects: Three Innovative Cases from Turkey. Published Magister Architecture Thesis, Middle East Technical University.

Altan H., Gasperini N., Moshaver, S., \& Frattari, A. (2015). Redesigning Terraced Social Housing in the UK for Flexibility Using Building Energy Simulation with Consideration of Passive Design. Journal of Sustainability, 7, 5488-5507.

Building \& Construction Authority Singapore. (2000) Modular coordination. BCA Buildability Series, Singapore.

Chaplin, J.P. (2002). Dictionary of Psychology. Dell Publishing Co. Inc., New York.

Ching, F.D.K. (1994). Architecture: Form, Space, and Order. John Wiley \& Sons, Inc., USA.

Farrow R.J., Labrador, A.C., \& Crews, J.D. (2012). Road to Flexibility: Strategic Interventions. Website https://www.healthcaredesignmagazine. com/trends/architecture/road-flexibility-strategicinterventions/, accessed on May 27, 2017.

Fawcett W., Hughes, M., \& Ellingham, I. (2012). Quantifying the Benefits of Flexible Buildings. Proceedings of the conference Long Lasting Buildings in Urban Transformation, 146-153.
Franklin, B. (2006). Housing Tranformations: Shaping the Space of Twenty-First Century Living. Routledge, New York.

Frisky, H., \& Pramitasari, D. (2018). Skema Flexible Housing pada Perumahan tipe 36 di Yogyakarta. Unpublished Magister Architecture Thesis, Universitas Gadjah Mada.

Frisky, H., \& Pramitasari, D. (2018). Flexible Housing: Architectural Investment for Future House. The Proceedings of 12th SEATUC Symposium: Engineering Education and Research for Sustainable Development, 14 \& 70-80.

Gilani, G. (2012). Evaluating Flexibility Notions in Mass Housing of North Cyprus through Learning from Her Rural Vernacular Architecture. Published Magister Architecture Thesis, Eastern Mediterranean University.

Gosling J. (2008). Flexible buildings for an adaptable and sustainable future. Proceedings of 24th Annual ARCOM Conference, 115-124.

Groat, L.N., \& Wang, D. (2013). Architectural Research Methods, Second Edition. John Wiley \& Sons, Inc., Canada.

Iswati, T.Y. (2001). Perubahan Denah Rumah Tinggal di Kampung Dalam Yogyakarta. Unpublished Magister Architecture Thesis, Universitas Gadjah Mada.

Keputusan Menteri Pekerjaan Umum dan Perumahan Rakyat No. 552/KPTS/M/ 2016 about Batasan Penghasilan Kelompok Sasaran KPR Bersubsidi, Batasan Harga Jual Rumah Sejahtera Sejahtera Tapak dan Satuan Rumah Sejahtera Susun, Serta Besaran Subsidi Bantuan Uang Muka Perumahan,

Keputusan Menteri Permukiman dan Prasarana Wilayah No. 403/KPTS/M/ 2002 about Pedoman Teknis Pembangunan Rumah Sederhana Sehat (Rs Sehat).

Kristiani, L. (1996). Perubahan Tata Ruang Banguan 'Rumah Usaha' di Prawirotaman Yogyakarta. Unpublished Magister Architecture Thesis, Universitas Gadjah Mada.

Li, S. (2014). A View of Flexible Housing in China. International Journal of Social, Behavioral, Educational, Economic, Business and Industrial Engineering, 8(4), 958-962.

Nugroho, P.S. (2002). Studi Perubahan Spasial Rumah Tinggal menjadi Rumah Pondokan Mahasiswa di Yogyakarta. Unpublished Magister Architecture Thesis, Universitas Gadjah Mada.

Pamungkas, L.S. (2005). Tipologi Perubahan Spasial Rumah Tinggal Pra Huni (Timoho Asri V, Yogyakarta). Unpublished Magister Architecture Thesis, Universitas Gadjah Mada. 
Peraturan Menteri PUPR No. 21/PRT/M/2016 about Kemudahan dan/atau Bantuan Perolehan Rumah Bagi Masyarakat Berpenghasilan Rendah.

Schnädelbach, H. (2010). Adaptive Architecture - A Conceptual Framework. Research Gate conference paper.

Schneider, T., \& Till, J. (2005). Flexible housing: opportunities and limits. Journal of Arq, 9(2), 157-166.

Schneider, T., \& Till, J. (2005). Flexible housing: the means to the end. Journal of Arq, 9(3), 287-196.

Schneider, T., \& Till, J. (2007). Flexible Housing. Routledge, New York.

Siregar, J.P. (2014). Metodologi dasar space syntax dalam analisis konfigurasi ruang. Universitas Brawijaya, Jakarta.

Sugini. (1997). Morfologi Perubahan Rumah pada Perumahan Minomartani Yogyakarta. Unpu- blished Magister Architecture Thesis, Universitas Gadjah Mada.

Till, J. (2008). Soft Space. University of Sheffield, Inggris.

Undang-Undang Republik Indonesia No. 1 tahun 2011 about Perumahan Dan Kawasan Permukiman.

Yu, J.G. (2011). American Dream 3.0: Flexible Urban Housing for Changing Life-styles. Unpublished Magister Architecture Thesis, University of Maryland.

Yudhohusodo, S. (1991). Rumah untuk Seluruh Rakyat. Bangun Cipta Pratama, Jakarta.

Živković, M., \& Jovanović, G. (2012). A Method for Evaluating the Degree of Housing Unit Flexibility in Multi-Family Housing. Journal of Architecture and Civil Engineering, 10(1), 17-32. 